Effects of catchment characteristics and landuse practices on water quality of Kotmale, Victoria, Randenigala, \& Rantambe reservoirs using GIS.

\author{
By \\ Kahawaththe Pitakotuwe Gedara \\ Wasantha Senadeera
}

Thesis submitted to the University of Sri Jayewardenepura for the award of the degree of Master of Philosophy in Limnology on $19^{\text {th }}$ May 2006 
"The work described in this thesis was carried out by me under the supervision of Professor (Mrs.) Swarna Piyasiri and Professor K.W.D. Nandalal and a report on this has not been submitted in whole or in part to any university or any other institution for another degree".

Sadeera

K.P.G.W. Senadeera 
"We certify that the above statement made by the candidate is true and that this thesis is suitable for submission to the University for the purpose of evaluation."
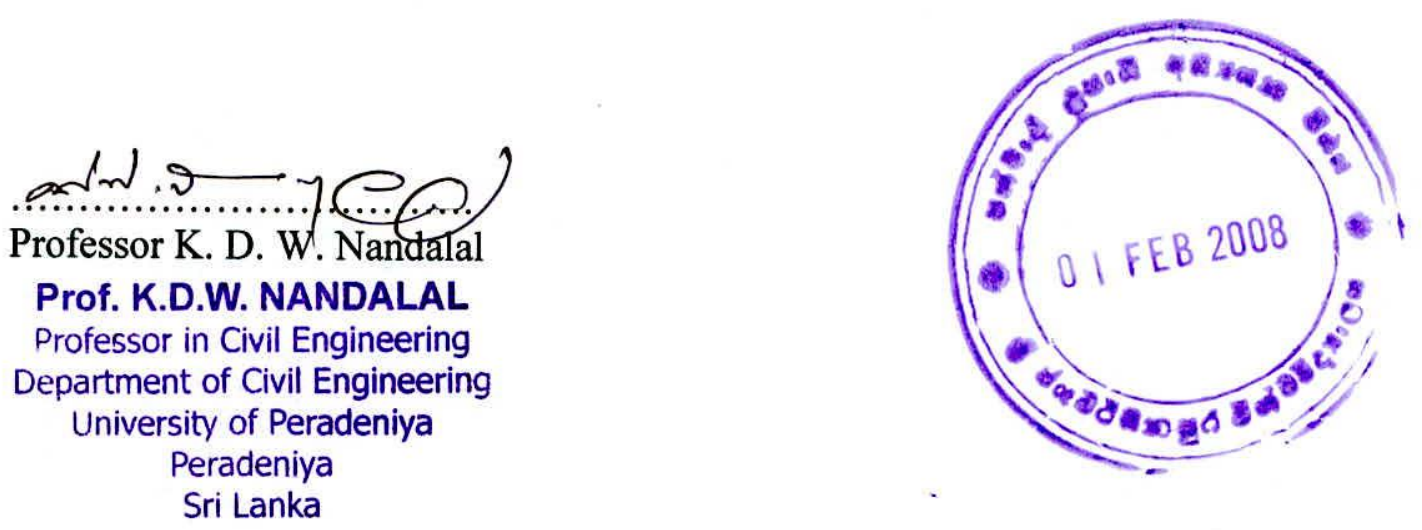


\section{Table of contents}

Table of contents

i

List of tables

viii

Figure captions

$\mathrm{x}$

List of plates

xv

Acknowledgements

xvii

Abstract

xviii

Chapter 1 - Introduction

1.0 Introduction

1

1.1 The study area - Upper Mahaweli Catchment (UMC)

2

1.2 The major Mahaweli reservoirs and their catchments

5

1.2.1 Kotmale

5

1.2.2 Victoria

1.2.3 Randenigala

1.2.4 Rantambe

1.2.5 The morphometric features of the reservoirs

1.3 The water quality and the catchments

1.3.1 Water quality standards

1.3.1.1 The water quality standards available in Sri Lanka

1.3.1.2 The water uses

1.4 The objectives

Chapter 2 - Literature survey

$2.1 \quad$ Water quality

2.1.1 Physical properties

2.1.1.1 Light

2.1.1.2 Thermal properties and density of water

2.1.2 Chemical properties

2.1.2.1 Dissolved oxygen

2.1.2.2 Alkalinity 
2.1.2.3 Conductivity

2.1.2.4 $\mathrm{pH}$

2.1.2.5 Hardness

2.1.2.6 Nitrate

2.1.2.7 Phosphate

2.1.2.8 Total Dissolved Solid 28

2.1.2.9 Sulfate 28

2.1.2.10 Chloride 29

2.1.3 Biological properties 29

2.2 Factors effecting Water Quality 31

2.2.1 The natural factors 32

2.2.1.1 The Morphometry of catchments

2.2.1.1.1 Measured parameters 32

2.2.1.1.2 Calculated parameters

2.2.1.2 The soils of the study area 38

2.2.1.3 Geology of the area 40

2.2.1.4 The Rainfall and Temperature

2.2.1.5 The Morphometry of water bodies

2.2.2 Anthropogenic activities

2.2.2.1 Soil erosion

2.2.2.2 Land uses

2.2.2.3 Population density

2.2.2.4 Waste disposal

2.2.2.5 Nutrients

2.2.2.6 Salt content

$2.3 \quad$ GIS as a tool

2.3.1 GIS Applications 53

2.3.1.1 Water pollution 53

2.3.1.2 GIS applications in Upper Mahaweli catchment 54

2.3.1.3 Malaria epidemics

2.3.1.4 Other applications 56 
$3.1 \quad$ Study area and sampling locations for water quality studies 58

3.2 Data analysis 58

3.2.1 The digital data of the sub catchments 58

$\begin{array}{lll}3.2 .2 & \text { The water quality data } & 63\end{array}$

3.2.3 Integrating catchment characteristic and water quality problems $\quad 64$

3.3 The catchment characteristics $\quad 65$

3.3.1 Morphometric features of sub catchments of UMC $\quad 65$

$\begin{array}{lll}3.3 .1 .1 & \text { Catchment area } & 65\end{array}$

3.3.1.2 Length of the basin 66

$\begin{array}{lll}\text { 3.3.1.3 Perimeter of the catchment } & 67\end{array}$

$\begin{array}{lll}3.3 .1 .4 & \text { Stream order } & 67\end{array}$

$\begin{array}{lll}3.3 .1 .5 & \text { Form factor } & 68\end{array}$

$\begin{array}{lll}\text { 3.3.1.6 Compactness factor } & 68\end{array}$

$\begin{array}{lll}\text { 3.3.1.7 Average slope } & 68\end{array}$

$\begin{array}{lll}3.3 .1 .8 & \text { Circulatory ratio } & 69\end{array}$

$\begin{array}{lll}3.3 .1 .9 & \text { Elongation ratio } & 70\end{array}$

$\begin{array}{ll}3.3 .1 .10 \quad \text { Length of overland flow } & 70\end{array}$

$\begin{array}{lll}3.3 .1 .11 & \text { Drainage density } & 70\end{array}$

$\begin{array}{lll}3.3 .1 .12 & \text { Stream frequency } & 71\end{array}$

3.3.1.13 Bifurcation ratio 71

$\begin{array}{lll}3.4 & \text { The morphometric features of the reservoirs } & 72\end{array}$

$\begin{array}{lll}3.5 & \text { Rainfall of the area } & 72\end{array}$

3.6 Qualitative assessment of soil erosion potential areas in the reservoir

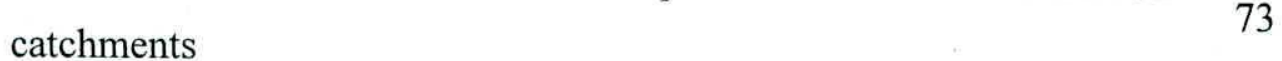

3.6.1 Assessment of soil erosion potential areas 73

$\begin{array}{lll}3.6 .2 & \text { Erosivity of rainfall } & 74\end{array}$

$\begin{array}{lll}3.6 .3 & \text { Erodibility } & 74\end{array}$

$\begin{array}{lll}3.6 .4 & \text { Slope length factor } & 75\end{array}$

$\begin{array}{lll}\text { 3.6.5 Cover and management factor } & 75\end{array}$

$\begin{array}{lll}3.6 .6 & \text { Support practice factor } & 76\end{array}$

$\begin{array}{lll}3.6 .7 & \text { Spatial analysis } & 76\end{array}$ 
3.6.8 Standard deviation

3.6.9 Natural breaks $\quad 77$

$\begin{array}{lll}\text { 3.6.10 Field verification on analyzed data } & 79\end{array}$

Chapter 4- Results $\quad 80$

$4.1 \quad$ Reservoir water quality $\quad 80$

4. 1.1 Water Level Fluctuations \& mixing properties 80

4.1.1.1 Kotmale reservoir $\quad 81$

4.1.1.2 Victoria reservoir $\quad 83$

4.1.1.3 Randenigala reservoir 83

4. 1.1.4 Rantambe reservoir 83

$\begin{array}{lll}\text { 4.1.2 Water transparency } & 84\end{array}$

4.1.3 Chlorophyll density $\quad 88$

4.1.4 Thermal behavior of the reservoirs 88

$\begin{array}{lll}4.1 .5 & \text { Dissolved oxygen } & 90\end{array}$

$\begin{array}{lll}\text { 4.1.6 Conductivity } & 91\end{array}$

4.1.6.1 Kotmale reservoir 91

4.1.6.2 Victoria reservoir 92

4.1.6.3 Randenigala reservoir $\quad 92$

4.1.6.4 Rantambe reservoir $\quad 92$

$\begin{array}{lll}4.1 .7 & \mathrm{pH} & 101\end{array}$

$\begin{array}{lll}4.1 .8 & \text { Alkalinity } & 101\end{array}$

$\begin{array}{lll}4.1 .9 & \text { Total Carbondioxide } & 105\end{array}$

4.1.10 Water Hardness 106

$\begin{array}{lll}4.1 .11 & \text { Chloride } & 110\end{array}$

$\begin{array}{lll}4.1 .12 & \text { Sulfate } & 110\end{array}$

$\begin{array}{lll}4.1 .13 & \text { Nitrate } & 113\end{array}$

$\begin{array}{lll}\text { 4.1.14 Phosphate } & 119\end{array}$

$\begin{array}{lll}4.1 .15 & \text { Nitrite } & 125\end{array}$

4.1.16 Sulphide \& Ammonia 129

4.2 Water quality of the tributaries 130

$\begin{array}{lll}\text { 4.2.1 Tributaries of Kotmale reservoir } & 130\end{array}$ 
4.2.2 Tributaries of Victoria reservoir 130

4.3 Factors contributing to degradation of Water quality 139

$\begin{array}{lll}4.3 .1 \quad N a t u r a l ~ f a c t o r s & 140\end{array}$

$\begin{array}{lll}\text { 4.3.1.1 Morphometric features } & 140\end{array}$

4.3.1.1.1 Catchment area and reservoir area $\quad 141$

4.3.1.1.2 Mean slope 145

4.3.1.1.3 Axial length \& basin width 147

$\begin{array}{lll}\text { 4.3.1.1.4 Basin shape } & 148\end{array}$

4.3.1.1.5 Stream network 150

4.3.1.2 Rainfall 160

4.3.1.3 Geology 168

4. 3.1.3.1 Rock types of the study area 168

4. 3. 1.4 Soil types of the area 178

$\begin{array}{lll}\text { 4.3.2 Anthropogenic activities } & 185\end{array}$

$\begin{array}{lll}\text { 4.3.2.1 Land use practices } & 185\end{array}$

4.3.2.2 Population, housing and waste densities of the catchments 195

4.3.2.2.1 Population density of the four catchments 195

4.3.2.2.2 Housing density of the four catchments 202

4.3.2.2.3 Waste density of the four catchments 206

4.3.3 Interaction of natural \& anthropogenic factors on water quality 210

$\begin{array}{lll}\text { 4.3.3.1 Soil erosion by map analysis } & 210\end{array}$

4.3.3.1.1 Kotmale reservoir $\quad 210$

$\begin{array}{lll}\text { 4.3.3.1.2 Victoria reservoir catchment } & 217\end{array}$

4.3.3.1.3 Randenigala reservoir catchment $\quad 226$

4.3.3.1.4 Rantambe reservoir catchment 233

4.3.3.2 Field verification of soil erosion potential areas 241

4.3.3.2.1 Extremely high erosion areas in the catchments 246

4.3.3.2.2 Very high erosion areas in the catchments 252

4.3.3.2.3 High erosion areas in the catchments 259

4.3.3.2.4 Moderate erosion areas in the catchments 265

4.3.3.2.5 Low erosion areas in the catchments 272

4.3.3.3 Overall catchment effects on high conductivity \& nutrients in the right 278 
bank tributaries of Victoria reservoir

4.3.3.3.1 Analysis of catchment characteristics in left \& right banks of the Victoria reservoir

4.3.3.4 Nutrient loading effect on Kotmale reservoir through Kotmala oya \& Kuda Oya sub catchment

4.3.3.4.1 Nutrient loading through Kotmala oya sub catchment 296

4.3.3.4.2 Nutrient loading through Kuda oya sub catchment 301

$\begin{array}{ll}\text { Chapter 5-Discussion } & 304\end{array}$

$5.1 \quad$ Physiochemical properties of the reservoirs 304

5.1.1 Physical properties of the reservoirs 306

5.1.1.1 Thermal stratification and mixing 308

5.1.2 Chemical properties of the reservoirs 310

5.1.3 Water quality of tributaries 323

5.2 Factors contributing to degradation of water quality 324

$\begin{array}{lll}5.2 .1 & \text { Natural factors } & 324\end{array}$

5.2.1.1 Catchment Morphometry $\quad 324$

5.2.1.1.1 Catchment area $\quad 325$

$\begin{array}{lll}5.2 .1 .1 .2 & \text { Basin shape } & 328\end{array}$

5.2.1.1.3 Stream network 329

5.2.1.2 Rainfall 333

5.2.1.3 Geology 335

$\begin{array}{lll}5.2 .1 .4 & \text { Soil } & 338\end{array}$

5.2.2 Anthropogenic activities 339

5.2.2.1 Landuse practices 339

$\begin{array}{lll}\text { 5.2.2.2 Population density } & 345\end{array}$

$\begin{array}{lll}5.2 .2 .3 \text { Housing } & 347\end{array}$

5.2.2.4 Waste density 347

5.3.1 Soil erosion in the Upper Mahaweli Catchment 349

5.3.2 Reservoir sedimentation 356

$6 \quad$ Conclusions $\quad 360$

$7 \quad$ References $\quad 362$ 
Appendices

Appendix I: Proposed Sri Lankan water quality standards

Appendix II: Materials and methods used in water quality analysis 383

Appendix III: Usage of fertilizer for major crops in Sri Lanka 384

Appendix IV: GPS points for validation of erosion potential locations List of Paper Publications and Communications from thesis 385 390 


\section{List of tables}

1.1 Summary of Geographic, Morphometric, Hydrological \& climatic data of Kotmale, Victoria, Randenigala \& Rantambe reservoirs

4.1 Summary of the statistical analysis of some water quality data of Kotmale, Victoria, Randenigala \& Rantambe reservoirs.

4.2 Summary of Water Quality data of the left and right bank tributaries of Kotmale reservoir from 1993 to 2003 based on statistical data analysis

4.3 Water quality of the left and right bank tributaries of Victoria reservoir.

4.4a Summary of water quality problems, reasons \& possible catchments characteristics to be examined under the present study

4.4b Morphometry of Kotmale, Victoria, Randenigala \& Rantambe Reservoirs

4.5 Composition of rock types in the catchments of Kotmale, Victoria, Randenigala and Rantambe

4.6 Soil types \& their distribution within the four catchments

4.7 The land use practices within the four catchments

4.8 Population, waste density \& housing densities within the four catchments.

4.9 Soil erosion hazard classes of Kotmale reservoir based on the results of map analysis.

4.10 Extents of each soil erosion hazard classes in Victoria reservoir catchment

4.11 Extents of each soil erosion hazard classes in Randenigala catchment 230

4.12 Extents of each soil erosion hazard classes in Rantambe catchment 238

4.13 Percentage area values of landuse, geology and soil types of Victoria left and right banks sub catchments

4.14 Estimates of soil loss by soil type \& slope

4.15 Estimated annual soil loss by erosion in the Upper Mahaweli Catchment 
4.16 Including divisional secretaries and pradesiya sabas of sub catchments

4.17 Landuse, geology and soil types of Kotmala oya and Kuda oya in Kotmale reservoir catchment

5.1 Sedimentation in the reservoirs of UMC 


\section{Figure captions}

1.1 Location of Upper Mahaweli Catchment within the Mahaweli river basin.

1.2 Origin of Mahaweli river and its location within the Mahaweli river basin.

1.3 The sub catchments of Upper Mahaweli Catchment.

$1.4 \quad$ Upper Mahaweli Catchment, Major tributaries and the reservoirs.

Water distribution pattern of accelerated Mahaweli project

Schematic diagram of UMC.

Sampling stations in Kotmale reservoir \& its tributaries

3.3 Sampling stations of Randenigala reservoir

3.4 Sampling stations of Rantambe reservoir

3.5 Method used in defining catchment boundary.

3.6 Flow chart of spatial analysis.

4.1 Water level fluctuations \& Secchi depth values in Kotmale, Victoria, Randenigala and Rantambe reservoirs.

4.2a Secchi depth size classes of Kotmale, Victoria, Randenigala and Rantambe reservoirs.

$4.2 \mathrm{~b}$ The frequency percentages of Secchi depth size classes in Kotmale reservoir during 1991 observation period.

4.3a Distribution of Choloraphyll-a $(\mathrm{mg} / \mathrm{l})$ content on the surface of the Kotmale reservoir from 1991 to 1995 period.

4.3b High chlorophyll-a values were initially observed at the upstream region where bloom formation was initiated, then due to the wave action it was shifted towards the dam.

4.3c Chlorophyll-a in Kotmale reservoir in 1991 during the bloom.

4.4a Thermal stratification of Kotmale reservoir from 1991-2000 at St1(Closer to dam)

4.4b Thermal stratification of Victoria reservoir 19912000 at st2 
4.4c Thermal stratification of Randenigala reservoir from 1996-2000 at ST3 (Dam)

4.4d Thermal properties of Rantambe reservoir from 1993-2000 at St1 (Dam)

4.5a -b Distribution of dissolved Oxygen in Kotmale and Victoria reservoirs closer to the dam at surface middle and bottom regions from 19902000.

4.5c-d Distribution pf dissolved Oxygen at surface middle and bottom regions in Randenigala and Rantambe reservoirs closer to the dam from 1993-2000 and 1993-2002 respectively.

4.6 a Conductivity observed in Kotmale, Victoria, Randenigala and Rantambe reservoirs.

4.6b Conductivity size classes in Kotmale, Victoria, Randenigala and Rantambe reservoirs.

4.7a PH distribution with depth at St1 of Kotmale reservoir 1990-2000 102

4.7b $\quad \mathrm{bH}$ values with depth at St2 of Victoria reservoir 1991-2000 103

4.7c $\mathrm{pH}$ distribution at St3 of Randenigala reservoir 1991-2000 104

4.7d $\mathrm{pH}$ values with depth at St1 of Rantambe reservoir 1993-2000 105

4.8 Alkalinity in Kotmale, Victoria, Randenigala and Rantambe reservoirs.

4.9 Total carbondioxide in Kotmale, Victoria, Randenigala and Rantambe reservoirs.

4.10 Water Hardness in Kotmale, Victoria, Randenigala and Rantambe reservoirs.

4.11 Chloride in Kotmale, Victoria, Randenigala and Rantambe reservoirs. $\quad 111$

4.12 Sulphate in Kotmale, Victoria, Randenigala and Rantambe reservoirs. $\quad 112$

4.13a-b Nitrate distribution with depth at St1 of Kotmale reservoir 1991-2000 114

4.13c-d Nitrate concentration with depth at St2 of Victoria reservoir 19912000

4.13e-f Nitrite concentration at St3 of Randenigala reservoir 1995-1999

4.13g Nitrate concentration at St1 of Rantambe reservoir 1993-2000 
4.13h Nitrate size classes in Kotmale, Victoria, Randenigala and Rantambe reservoirs based on data collected from all the sampling locations during entire sampling period.

4.14a-b Phosphate concentration at St1 of Kotmale reservoir 1990-2000

4.14c-d Phosphate concentration at St2 of Victoria reservoir 1996,1997 \& 2000

4.14e-f Phosphate concentration at St3 of Randenigala reservoir 1990-2000

4.14g-h Phosphate concentration closer to the dam at St1 of Rantambe reservoir 1993-2000

4.14i Phosphate size classes in Kotmale, Victoria, Randenigala and Rantambe reservoirs.

4.15a-b Nitrite concentration with depth at St1 of Kotmale reservoir 19912000

4.15c-d Nitrite distribution at St2 of Victoria reservoir 1991-2000

4.15e-f Nitrite concentration at St3 of Randenigala reservoir 1995-1999

4.16 Summary of the key catchment morphometric features of Kotmale, Victoria, Randenigala and Rantambe reservoirs. The figures are drawn to scale.

4.17 Average slope of four catchments.

4.18 Form factor compactness factor, circulatory ratio, elongation and Bifurcation ratio of the catchments.

4.19 Stream network of Kotmale reservoir.

4.20 Stream network of Victoria reservoir. 152

$4.21 \quad$ Stream network of Randenigala reservoir 153

4.22 Stream network of Rantambe reservoir. $\quad 154$

$4.23 \quad$ Stream order vs. of number of streams 156

4.24 Mean stream lengths vs. stream orders 156

4.25 Streams frequency and drainage density of the catchments. 157

$\begin{array}{ll}4.26 & \text { Bifurcation ratios of the catchments. }\end{array}$

4.27 The length of overland flow 158

4.28 Length of overland flow of the catchments 159

4.29.1 Rainfall distribution patterns of average Annual, Yala and Maha (mm) $\quad 161$ 
in the catchment of Kotmale.

4.29.2 Rainfall distribution patterns of average Annual Yala and Maha (mm) in the catchment of Victoria.

4.29.3 Rainfall distribution patterns of average Annual, Yala and Maha (mm) in the catchment of Randenigala.

4.29.4 Rainfall distribution patterns of average Annual, Yala and Maha (mm) in the catchment of Rantambe.

4.30.1 Geology types of Kotmale and Victoria catchments.

4.30.2 Geology Types of Randenigala and Rantambe catchments. 170

4.30.3 Comparison of rock types in the four reservoir catchments. 174

4.31.1 Soil types of Kotmale and Victoria catchments. 182

4.31.2 Soil types of Randenigala and Rantambe catchments. 183

4.31.3 The comparison of soil types in the four reservoir catchments. 184

4.32.1 Landuse types of Kotmale and Victoria catchments. 187

4.32.2 Landuse types of Randenigala and Rantambe catchments. 188

4.32.3 Comparison of landuse practices within the four reservoir catchments. 189

4.33.1 Population density $\left(\right.$ per $\left.\mathrm{km}^{2}\right)$ of Kotmale and Victoria catchments. 196

4.33.2 Population density (pre $\mathrm{km}^{2}$ ) of Randenigala and Rantambe reservoir. 197

$\begin{array}{lll}\text { 4.33.3 Population within the four catchments. } & 198\end{array}$

4.34.1 Housing density (per $\mathrm{km}^{2}$ ) of Kotmale and Victoria catchments. 203

4.34.2 Housing density (per $\mathrm{km}^{2}$ ) of Randenigala and Rantambe catchment. 204

4.34.3 Housing density of the four catchments. 205

4.35.1 Waste density (MT per $\mathrm{km}^{2}$ ) of Kotmale and Victoria catchments. 207

4.35.2 Waste density (MT per $\mathrm{km}^{2}$ ) of Randenigala and Rantambe catchments.

4.35.3 The Waste densities in the four catchments. 209

4.36.1 \& Soil types and rainfall erosivity of Kotmale catchment 211

4.36.3 \& Slope length factor and landuse types of Kotmale catchment.

4.36.5 Soil erosion hazard classes of Kotmale catchment. 213

4.37.1 \& Soil types and rainfall erosivity of Victoria catchment 219 
4.37.3 \& Slope length factor and landuse types of Victoria catchment.

4.37.5 Soil erosion hazard classes of the Victoria catchment.

4.38.1 \& Soil types and rainfall erosivity of Randenigala catchment.

4.38.3 \& Slope length factor and landuse types of Randenigala catchment

4.38.5 Soil erosion hazard classes of Randenigala catchment.

4.39.1 \& Soil types and rainfall erosivity of Rantambe catchment.

4.39.3 \& Slope length factor and landuse types of Rantambe catchment.

4.39.5 Soil erosion hazard classes of the Rantambe catchment

4.39.6.1 GPS validate points in Kotmale catchment

4.39.6.2 GPS validate points in Victoria catchment

4.39.6.3 GPS validate points in Randenigala catchment

4.39.6.4 GPS validate points in Rantambe catchment

4.40.1a \& Landuse and geology types of the left and right bank sub catchments

4.40.2a of Victoria

4.40.1b Landuse types of sub catchments of left and right bank of Victoria reservoir

4.40.2b Geology types of sub catchments of left bank and right bank of Victoria reservoir

4.40.3a \& Soil types and population density of the left and right bank sub

\subsection{4 catchments of Victoria}

4.40.3b Soil types of sub catchments of left and right bank of Victoria reservoir

4.40.5 \& Housing and waste densities of the left and right bank sub catchments

4.40.6 of Victoria

4.41.1 Extent of landuse, geology and soil types of Kotmala oya sub catchment. 


\section{List of plates}

4.1 Around Kotmale dam 247

4.2 Cleared area at Diagama east, Kotmale catchment 247

4.3 Cleared area at Harandalwattha, Victoria catchment 249

4.4 Tea plantation at Harandalwattha Victoria catchment 249

4.5 Grassland at Handungalawattha, Victoria catchment 250

4.6 Grassland at Diyagala, Victoria catchment 250

4.7 Open area at Millagahamulla, Victoria catchment 251

$4.8 \quad$ Terraces at Millapitiya, Randenigala catchment 253

$4.9 \quad$ Open forest at Malapattawa, Randenigala catchment 253

4.10 Grassland at Galledanda, Rantambe catchment 254

4.11 Tea plantation at Albion, Kotmale catchment 255

4.12 Grassland at Pundalu oya, Kirinusan, Kotmale catchment 255

4.13 Terraces at Millagahamulla, Victoria catchment 256

$4.14 \quad$ Home-garden at Warakalawita, Victoria catchment 256

4.15 Open forest at Randenigala, Randenigala catchment 257

4.16 Terraces at Munwatta, Randenigala catchment 257

4.17 Rantambe left bank, Rantambe catchment 258

4.18 Paddy \& home-garden at Malhewa, Kotmale 260

4.19 Tea plantation at Watagoda, Kotmale catchment 260

4.20 Forest plantation at Galaha, Victoria catchment 261

$4.21 \quad$ Forest plantation at Gomera, Victoria catchment 261

$4.22 \quad$ Forest plantation at Harandal, Victoria catchment 262

4.23 Tea plantation at Shanon, Victoria catchment 262

$4.24 \quad$ Angilibedda, Randenigala catchment 263

4.25 Paddy filed at Denipe, Randenigala catchment 263

4.26 Paddy field at Mahawela, Rantambe catchment 264

4.27 Forest plantation at Hatkinda, Rantambe catchment 264

4.28 Paddy filed at Mawela, Kotmale catchment 266

4.29 Tea plantation at Dunukedeniya, Kotmale catchment 266

4.30 Homegarden at Ambewela, Kotmale catchment 267 
4.31 Open forest at Horton plain, Kotmale catchment 267

4.32 Forest plantation at Panwila, Victoria catchment 269

4.33 Tea plantation at Punchiwatta, Victoria catchment 269

$4.34 \quad$ Tea plantation at Rangala, Victoria catchment 270

4.35 Vegetable at Galledanda, Rantambe catchment 270

4.36 Vegetable at Boragassa, Rantambe catchment 271

$4.37 \quad$ Forest plantation at Rojesangama, Kotmale catchment 273

$4.38 \quad$ Homegarden at Ruwaneliya, Kotmale catchment 273

4.39 Natural forest at Horton plain, Kotmale catchment 274

4.40 Paddy filed at Hedeniya Victoria catchment 274

4.41 Homegarden at Watawala, Victoria catchment 275

4.42 Tea plantation at Lunuwatta, Rantambe catchment 275

$4.43 \quad$ Natural forest at Hakgala, Rantambe catchment 276

4.44 Forest plantation at Ambewela, Rantambe catchment 276 


\section{Acknowledgements}

I am grateful to my supervisors, Professor (Mrs.) Swarna Piyasiri and Professor K. D. W. Nandalal, for their excellent advice, guidance, suggestions, criticism and encouragement throughout this study to make it a success.

I greatly appreciate cooperation and the help of Mr. Wijewickrama, National Building Research Organization, and Mr. Kapila Munasinghe, Natural Resource Management Center of the Department of Agriculture at Peradeniya, Sri Lanka for providing necessary data and literatures.

I wish to acknowledge Mr. Nalin De Silva of Geological Survey and Mines Bureau for providing geological data of Upper Mahaweli Catchment.

I appreciate the financial assistance provided by National Science Foundation, Sri Lanka under the research grant number RG/2001/E/01.

I am grateful to Headworks Administration, Operation and Maintenance unit of the Mahaweli Authority of Sri Lanka for providing necessary facilities in the field for data collection.

I am grateful to Mr. L. H. Indrasiri, Urban Development Authority of Sri Lanka for providing GIS training course and map scanning facilities.

I appreciate the kind help of Dr. Sterin Fernando of Geological Survey and Mines Bureau for providing some literatures.

I would also like to thank all the staff members of the Department of Zoology University of Sri Jayewardenepura for their kind cooperation \& help during my stay in the department.

I wish to thank my colleagues, Mr. Chandana Abeysinghe and Mr. Nalin Suranga for their encouragement and kind corporation.

I acknowledge cooperation extended by Mr. Deepasiri and other drivers who took me to field visits. 


\title{
Effects of catchment characteristics and landuse practices on water quality of Kotmale, Victoria, Randenigala \& Rantambe reservoirs using GIS.
}

\author{
K. P. G. W. Senadeera
}

\begin{abstract}
The Upper Catchment of Mahaweli Ganga is located within the mountainous core of the central highland of Sri Lanka, which covers $3110 \mathrm{~km}^{2}$; about $29.8 \%$ of the Mahaweli river basin, and $4.5 \%$ of the country. Study area of the present investigation is the Upper Mahaweli catchment and the four major hydropower reservoirs, namely Kotmale, Victoria, Randenigala and Rantambe. The water quality of the reservoirs was investigated since 1987 and the results indicated deterioration of water quality of the reservoirs with the time.
\end{abstract}

The main objective of the present study was to find out the effects of land use patterns and the interactive catchment characteristics, on water quality of Kotmale, Victoria, Randenigala \& Rantambe reservoirs using GIS as an analytical tool.

In order to achieve the objectives, the physical, chemical \& some biological data of the reservoirs were analyzed to identify the major water quality problems of the reservoirs and the analysis of catchment characteristics was conducted to find out the effect of catchment characteristics on the water quality deteriorations.

The water level fluctuations of the three reservoirs played an important role in the lake metabolism. During monsoons the reservoir water levels were high with the tendency for direct stratification whereas there was a tendency for mixing during droughts due to drop down of water levels. However Rantambe reservoir was subjected to frequent mixing due to its shallow nature. 
Secchi depth transparency values of the four reservoirs were $1.8-2.5 \mathrm{~m}$ in Kotmale, 2.3 to $3.2 \mathrm{~m}$ in Victoria, $2.8-4.1 \mathrm{~m}$ in Randenigala $\&<=1.0 \mathrm{~m}$ in Rantambe during the 15 year investigation period. Out of the four reservoirs, Kotmale reservoir was the most sensitive reservoir towards eutrophication \& Rantambe indicated high turbidity due to soil erosion in the catchment. Randenigala indicated mesotrophic to oligotrophic condition.

The vertical temperature readings indicated the direct thermal stratification in Kotmale, Victoria \& Randenigala reservoirs. However there was no thermal stratification in Rantambe reservoir due to its shallow nature. In Kotmale, Victoria and Randenigala reservoirs, Dissolved Oxygen concentrations at the bottom region dropped below $1 \mathrm{mg}$ /l during 1990 \& 1991 sampling periods. The dissolved Oxygen concentration in Rantambe at the bottom region was well above $3 \mathrm{mg} / \mathrm{l}$. The mean conductivity values indicated an increasing tendency with their altitudes from Kotmale to Randenigala. In Kotmale, Victoria \& Randenigala reservoirs, $\mathrm{pH}$ values of the surface waters indicated values expected from natural fresh water bodies. However the $\mathrm{pH}$ values of the bottom hypolimnetic waters indicated slightly acidic conditions. Alkalinity of the four reservoirs ranged from 0.2 to $1.2 \mathrm{mg} / \mathrm{l}$. and the total carbon dioxide levels ranged from $0.2-1.8 \mathrm{mg} / \mathrm{l}$. There was an increasing trend of hardness with decreasing altitude of the reservoirs, which ranged from $0.2-1.2 \mathrm{~m} \mathrm{~mol} / \mathrm{l}$. Chloride levels in the four reservoirs closer to the dam varied from $6-15 \mathrm{mg} / \mathrm{l}$. Sulphate fluctuations closer to the dam region of the reservoirs ranged from $0.2-2.5 \mathrm{mg} / \mathrm{l}$. Distribution of Nitrate along the vertical profile of the reservoirs closer to the dam indicated increasing trend with the time indicating nutrient loading effect. Phosphate concentration closer to the dam of the reservoirs ranged from $0.1-0.7 \mu \mathrm{g} / \mathrm{l}$. Distribution of Nitrite of the reservoirs indicated increasing tendency with the time.

Out of the tributaries of Kotmale reservoir, the Kotmala Oya tributary indicated high Nitrate values of 0.8 to $1.2 \mathrm{mg} / \mathrm{l}$ and 0.7 to $1.37 \mathrm{mg} / \mathrm{l}$ by Kuda Oya indicating their contribution towards nutrient loading effect during the 15 year investigation. Most of the tributaries in left \& right banks indicated high Phosphate levels. Tributaries in the right bank of Victoria reservoir indicated significantly high alkalinity, chloride, 
conductivity, hardness, nitrate, nitrite, phosphate, $\mathrm{pH}$, total carbon dioxide and turbidity compared to the left bank tributaries.

According to the GIS analysis of the morphometric features of the catchments of the reservoirs, (based on catchment area, compactness factor bifurcation ratio, length of overland flow, drainage density, perimeter etc) the highest effects towards water quality deterioration was indicated by the Rantambe catchment \& the least effect from Randenigala reservoir catchment. Other natural factors such as rainfall, geology, and soil characteristics, and anthropogenic activities such as population density, waste density, changing land use pattern indicated a significant influence on the water quality according to the GIS analysis of the catchment characteristics.

Based on the analysis of digital data of UMC area, soil erosion of the catchments indicated an extent of $70.37 \mathrm{~km}^{2}$ of extremely high erosion, $307.0 \mathrm{~km}^{2}$ of very high erosion, $716.19 \mathrm{~km}^{2}$ of high erosion and over $1065 \mathrm{~km}^{2}$ of moderate erosion areas. Low erosion areas were distributed over $949.62 \mathrm{~km}^{2}$ of the four catchments.

The overall analysis of the digital data of natural \& anthropogenic activities of the four catchments indicated the potential for the deterioration of water quality of the reservoirs due to catchment characteristics \& the land use practices. 